\title{
Searching Process using Bayer Moore Algorithm in Medicinal Information Media
}

\author{
Irma Anggraeni, Mulyati
}

\begin{abstract}
Indonesia is one of the giant centers of biodiversity, there are many types of plants that can be used as a medicine. Based on medicinal plants collection of Bogor Botanical Garden which has the potential as medicine consists of 764 species, 465 genus and 135 families. So in search of herbs manually becomes difficult. Therefore, to facilitate the search for information about the plume of drugs, required an effective and easy to use information media by the community. In this research we used Boyer Moore algorithm to execute the searching process. This research shows the process of string matching using a Boyer-Moore algorithm in the form of visual simulation by doing string searching of a pattern string, The results show that the algorithm can be used to the searching process.
\end{abstract}

Keyword : Boyer Moore Algorithm, medicinal plant, searching process.

\section{INTRODUCTION}

Information on medicinal plants is now widely presented in the form of software both in the web, desktop applications and also in the form of mobile. So this will help many users to find information on the type of medicinal plants that neede or want to find. There are application of medicinal plants based on mobile using sequential algorithm for search system. With the search engine in an application will help users in finding the desired word. By typing the word you want to search on the search engine then all the desired information will be displayed. However, according to Benisius [1] a number of research on the search engine concluded that many mistakes made by users in typing the word sought. If this tiredness occurs then the user will find it difficult to get the desired information. To facilitate users in searching for words in the information of medicinal plants it is necessary to add features that can help to do so. Such as the searching process. Searching process usually uses string matching algorithms. The string matching algorithm usually use two inputs, there are a short string called a pattern and a long string called a text. String matching algorithms are the basic components of existing applications, such as text processing, intrusion detection, search analysis, information retrieval, and computational biology [2]. One of the algorithms that can be used to get fires autocorrect in is Bayer Moore Algorithm. The algorithm has a string matching process from the right of the pattern to the left [3], the initial concept of the string-handling process from the right to get more information [4]. The BoyerMoore algorithm is one of the famous exact

Revised Manuscript Received on April 25, 2019.

Irma Anggraeni, Department of Computer Science, Faculty of Mathematics and Science, Pakuan University, Indonesia.

Mulyati, Department of Computer Science, Faculty of Mathematics and Science, Pakuan University, Indonesia. string matching algorithms that used in single pattern matching and it considers very fast in its performance [5]. The research conducted by Darmawan et al [6] who made a dictionary application for midwifery using the Boyer Moore algorithm as a web-based search. Siahaan and Mesran [7] who implement the Boyer Moore algorithm for Android-based baby name dictionary applications. This research tries to model in the simulation of string matching process using Boyer-Moore algorithm, it is expected for other researchers who wish to study or developed the Boyer-Moore algorithm to find out how the algorithm works.

\section{BAYER MOORE ALGORITHM}

The Boyer-Moore algorithm includes the most efficient string matching algorithm compared to other string matching algorithms due to an efficient nature of the algorithm, many string matching algorithms developed based on the concept of Boyer-Moore algorithm [8]. Boyer-Moore string searching algorithm is based on a comparing starts not from the beginning, but from the end of the pattern [9].

For the string search steps on the Boyer-Moore algorithm as follows:

a. First, we need two tables with Match Heuristic (MH), and Occurrence Heuristic $(\mathrm{OH})$ approaches to determine the number of shifts that will be performed on a pattern $(\mathrm{P})$ if there are unsuitable characters in the matching process of characters in text $(\mathrm{S})$. b. If in the comparison process there is character mismatch between the characters on $\mathrm{P}$ and $\mathrm{S}$, then the shift is done by looking at both tables with the largest shift value selected.

b. The possibility of completion in shifting to $\mathrm{P}$ is that if in previous matching there is no matching character then the shift is done by looking at the value of shift in occurrence heuristic table. If the character being compared does not exist in $\mathrm{P}$, then the shift is done as much as the number of characters contained in $\mathrm{P}$, but if the unsuitable character is contained in the P string, then the shift is done based on the table.

c. If the characters in the matching text match the characters on the $\mathrm{P}$ string, then the character checking position on $\mathrm{P}$ and $\mathrm{S}$ shifts each left position 1 from the previous position, then proceed with matching at that position and so on, then if there is a character mismatch

In $\mathrm{P}$ and $\mathrm{S}$, the shift is done by looking at the heuristic match table and the occurrence heuristic where the largest shift value to be selected is reduced by the number of matching characters. e. If all the characters have a match, that means $\mathrm{P}$ has been found in $\mathrm{S}$, then move the pattern by one character, continue until the end of the S pattern. 


\section{RESULT AND DISCUSSION}

In this section we analyze searching process using boyer Moore algorithm by taking word that contained in Medicinal Plant database.

Text (T): TEMULAWAK

Pattern (P):TEMULAWAK

Next step is to make table $\mathrm{MH}$ and $\mathrm{OH}$

Table 1. Value of $\mathrm{OH}$ and $\mathrm{MH}$

\begin{tabular}{|c|c|c|c|c|c|c|c|c|c|}
\hline $\mathrm{P}$ & $\mathrm{T}$ & $\mathrm{E}$ & $\mathrm{M}$ & $\mathrm{U}$ & $\mathrm{L}$ & $\mathrm{A}$ & $\mathrm{W}$ & $\mathrm{A}$ & $\mathrm{K}$ \\
\hline $\mathrm{OH}$ & 7 & 6 & 5 & 4 & 3 & 1 & 2 & 1 & 0 \\
\hline $\mathrm{MH}$ & 8 & 8 & 8 & 8 & 8 & 8 & 8 & 8 & 1 \\
\hline
\end{tabular}

1. First check characters $\mathrm{K}$ on pattern met with character $\mathrm{K}$ on text, result is match. Next match backwards to the left character.

\begin{tabular}{|l|l|l|l|l|l|l|l|l|}
\hline $\mathrm{t}$ & $\mathrm{e}$ & $\mathrm{m}$ & $\mathrm{u}$ & $\mathrm{l}$ & $\mathrm{a}$ & $\mathrm{w}$ & $\mathrm{a}$ & $\mathrm{k}$ \\
\hline $\mathrm{t}$ & $\mathrm{e}$ & $\mathrm{m}$ & $\mathrm{u}$ & 1 & $\mathrm{a}$ & $\mathrm{w}$ & $\mathrm{a}$ & $\mathrm{k}$ \\
\hline
\end{tabular}

Fig. 1. Step 1

2. Step 2 Character A on pattern met with character $\mathrm{A}$ in text, result is suitable, then next match next back to left.

\begin{tabular}{|l|l|l|l|l|l|l|l|l|}
\hline $\mathrm{t}$ & $\mathrm{e}$ & $\mathrm{m}$ & $\mathrm{u}$ & 1 & $\mathrm{a}$ & $\mathrm{w}$ & $\mathrm{a}$ & $\mathrm{k}$ \\
\hline $\mathrm{t}$ & $\mathrm{e}$ & $\mathrm{m}$ & $\mathrm{u}$ & 1 & $\mathrm{a}$ & $\mathrm{w}$ & $\mathrm{a}$ & $\mathrm{k}$ \\
\hline
\end{tabular}

Fig. 2. Step 2

3. Step $3 \mathrm{~W}$ character in pattern met with character $\mathrm{W}$ in text, character match occurs, then next process move towards left.

\begin{tabular}{|l|l|l|l|l|l|l|l|l|}
\hline $\mathrm{t}$ & $\mathrm{e}$ & $\mathrm{m}$ & $\mathrm{u}$ & $\mathrm{l}$ & $\mathrm{a}$ & $\mathrm{w}$ & $\mathrm{a}$ & $\mathrm{k}$ \\
\hline
\end{tabular}

\begin{tabular}{|l|l|l|l|l|l|l|l|l|}
\hline $\mathrm{t}$ & $\mathrm{e}$ & $\mathrm{m}$ & $\mathrm{u}$ & $\mathrm{l}$ & $\mathrm{a}$ & $\mathrm{w}$ & $\mathrm{a}$ & $\mathrm{k}$ \\
\hline
\end{tabular}

Fig. 3. Step 3

4. Next shift of character A on pattern met with character A in text, result match, then next process back to left.

\begin{tabular}{|c|c|c|c|c|c|c|c|c|}
\hline $\mathrm{t}$ & $\mathrm{e}$ & $\mathrm{m}$ & $\mathrm{u}$ & 1 & $\mathrm{a}$ & $\mathrm{w}$ & $\mathrm{a}$ & $\mathrm{k}$ \\
\hline $\mathrm{t}$ & $\mathrm{e}$ & $\mathrm{m}$ & $\mathrm{u}$ & 1 & $\mathrm{a}$ & $\mathrm{w}$ & $\mathrm{a}$ & $\mathrm{k}$ \\
\hline
\end{tabular}

Fig. 4. Step 4
5. Next shift $L$ character on pattern met with character $L$ in text, result match, then next process back to left

\begin{tabular}{|c|c|c|c|c|c|c|c|c|}
\hline $\mathrm{t}$ & $\mathrm{e}$ & $\mathrm{m}$ & $\mathrm{u}$ & $\mathrm{l}$ & $\mathrm{a}$ & $\mathrm{w}$ & $\mathrm{a}$ & $\mathrm{k}$ \\
\hline $\mathrm{t}$ & $\mathrm{e}$ & $\mathrm{m}$ & $\mathrm{u}$ & 1 & $\mathrm{a}$ & $\mathrm{w}$ & $\mathrm{a}$ & $\mathrm{k}$ \\
\hline
\end{tabular}

Fig. 5. Step 5

6. Next shift character $U$ on pattern met with character $U$ on text, result match, then next process back to left

\begin{tabular}{|c|c|c|c|c|c|c|c|c|}
\hline $\mathrm{t}$ & $\mathrm{e}$ & $\mathrm{m}$ & $\mathrm{u}$ & $\mathrm{l}$ & $\mathrm{a}$ & $\mathrm{w}$ & $\mathrm{a}$ & $\mathrm{k}$ \\
\hline $\mathrm{t}$ & $\mathrm{e}$ & $\mathrm{m}$ & $\mathrm{u}$ & 1 & $\mathrm{a}$ & $\mathrm{w}$ & $\mathrm{a}$ & $\mathrm{k}$ \\
\hline
\end{tabular}

Fig. 6. Step 6

7. Next shift of character $M$ in pattern met with character $M$ in text, result match, then next process back to left

\begin{tabular}{|l|c|c|c|c|c|c|c|c|}
\hline $\mathrm{t}$ & $\mathrm{e}$ & $\mathrm{m}$ & $\mathrm{u}$ & 1 & $\mathrm{a}$ & $\mathrm{w}$ & $\mathrm{a}$ & $\mathrm{k}$ \\
\hline $\mathrm{t}$ & $\mathrm{e}$ & $\mathrm{m}$ & $\mathrm{u}$ & 1 & $\mathrm{a}$ & $\mathrm{w}$ & $\mathrm{a}$ & $\mathrm{k}$ \\
\hline
\end{tabular}

Fig. 7. Step 7

8. Next shift character $E$ in pattern met with character $E$ in text, result match, then next process back to left.

\begin{tabular}{|c|c|c|c|c|c|c|c|c|}
\hline $\mathrm{t}$ & $\mathrm{e}$ & $\mathrm{m}$ & $\mathrm{u}$ & $\mathrm{l}$ & $\mathrm{a}$ & $\mathrm{w}$ & $\mathrm{a}$ & $\mathrm{k}$ \\
\hline $\mathrm{t}$ & $\mathrm{e}$ & $\mathrm{m}$ & $\mathrm{u}$ & 1 & $\mathrm{a}$ & $\mathrm{w}$ & $\mathrm{a}$ & $\mathrm{k}$ \\
\hline
\end{tabular}

Fig. 8. Step 8

1. Next shift of character $T$ in pattern met with character $T$ in text, result match, then next process back to left

\begin{tabular}{|l|c|c|c|c|c|c|c|c|}
\hline$t$ & $\mathrm{e}$ & $\mathrm{m}$ & $\mathrm{u}$ & $\mathrm{l}$ & $\mathrm{a}$ & $\mathrm{w}$ & $\mathrm{a}$ & $\mathrm{k}$ \\
\hline $\mathrm{t}$ & $\mathrm{e}$ & $\mathrm{m}$ & $\mathrm{u}$ & $\mathrm{l}$ & $\mathrm{a}$ & $\mathrm{w}$ & $\mathrm{a}$ & $\mathrm{k}$ \\
\hline
\end{tabular}

Fig. 9. Step 9

\section{CONCLUSION}

This application uses the boyer moore algorithm in the process of finding the word medicinal plants. Boyer algorithm performs the search process by doing word comparison starting from the right.

\section{REFERENCES}

1. B. Anu, Sistem pengkoreksian kata kunci dengan menggunakan metode levensthein distance: studi kasus pada webside universitas Halmahera. Doctoral dissertation, Universitas Gadjah Mada, 2010.

Published By: 
2. B. Kun, G. Nai-jie,T. Kun, L. Xiao-hu and L. Gang. "A practical distributed string matching algorithm architecture and implementation." World Acad Sci Eng Technol, vol. 10, pp. 1307-6884, 2005.

3. A. A. Alsaheel A. H. Alqahtani and A. M. Abdulatif. "Analysis of Parallel Boyer-Moore String Search Algorithm," Global Journal of Computer Science and Technology Hardware \& Computation, vol. 13, no. 1, pp. 43-47, 2013.

4. A. Z. M. Saleh, N. A. Rozali, A. G. Buja, K. A. Jalil, F. H. M.Ali, and T. F. A. Rahman. "A method for web application vulnerabilities detection by using boyer-moore string matching algorithm." Procedia Computer Science, vol. 72, pp. 112-121, 2015.

5. A. A. Hasan and N. A. A. "Rashid. Hash-Boyer-Moore-Horspool string matching algorithm for intrusion detection system." In International Conference on Computer Networks and Communication Systems, vol. 35, pp. 12-16, 2012

6. R. I. Darmawan, A. H. Setianingrum, and A. Arini. "Implementasi Algoritma Boyer Moore Pada Aplikasi Kamus Istilah Kebidanan Berbasis Web.” Query: Journal of Information Systems, vol. 2, no. 1, pp. $53-62,2018$

7. A. P. Siahaan and M. Mesran, "Implementasi algoritma boyer moore pada aplikasi kamus nama bayi beserta maknanya berbasis android." Pelita informatika: informasi dan informatika, vol. 17, no. 1, pp. 97-101, 2018.

8. R. Y. Tsarev, A. S. Chernigovskiy, E. A. Tsareva, V. V. Brezitskaya, A. Y. Nikiforov, and N. A. Smirnov. "Combined string searching algorithm based on knuth-morris-pratt and boyer-moore algorithms." IOP Conference Series: Materials Science and Engineering, vol. 122, no. 1, p. 012034, 2016.

9. R. Rahim, A. S. Ahmar, A. P. Ardyanti and D. Nofriansyah. "Visual Approach of Searching Process using Boyer-Moore Algorithm." Journal of Physics Conference Series. vol. 930, no. 1, p. 012001, 2017. 